\title{
Waste machines as an alternative way to enhance students' speaking interest
}

\author{
Yuliana Ningsih ${ }^{\mathrm{a}, 1,{ }^{*}, \text { Kurnia Dwi Artika }}{ }^{\mathrm{b}, 2}$ \\ ${ }^{\text {a,b }}$ Politeknik Negeri Tanah Laut, Jl. A. Yani No.Km.06, Pemuda, Kec. Pelaihari, Kabupaten Tanah Laut, Kalimantan Selatan 70815, Indonesia \\ ${ }^{1}$ yuliananingsih@politala.ac.id*; ${ }^{2}$ kurnia.2a@politala.ac.id \\ * corresponding author
}

ARTICLE INFO

Article history

Received 25 December 2019

Revised 7 March 2020

Accepted 10 August 2020

Available Online 15 January 2021

Keywords

waste machine

learning media

speaking interest

\begin{abstract}
The phenomenon this time was that many lecturers had fallen asleep with the technological advancements used in the learning media. By relying on a more unique creativity, this study used simple materials from spare parts of a machine that can be used as learning media especially in speaking interest. The paper aims to explore speaking interest through waste machines to the students of Mechanical Engineering, the State Polytechnic of Tanah Laut. It investigates how waste machines can be incorporated in English for Specific Purpose (ESP) learners' speaking interest. This study was qualitative case study, and data were gathered through observations, field notes and interviews. Data were interpreted based on the prepared achievements indicator. The results of the study reveal that the utilization of waste machines such as shocks, piston, gear, and bold is successful improving speaking skill for the students of Mechanical Engineering. In addition, students also learnt how to deliver in presentation with their field studies.
\end{abstract}

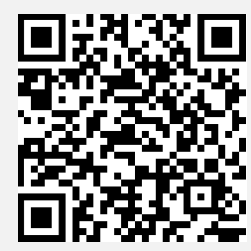

This is an open access article under the CC-BY-SA license.

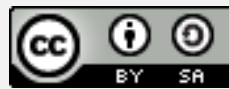

\section{Introduction}

The learning process has a close relationship with teachers/lecturers, some of them have acted as sources of information and also facilitators. Not only preparing the design of learning programs, various approaches have been made by teachers/lecturers to get good results, namely learners are easy to understand and feel comfortable with the learning process. At present, many learning media have been used by teachers/lecturers to facilitate the learning process, especially the use of media which is currently increasingly sophisticated. However, the thing that has become a phenomenon this time is many teachers/lecturers are lulled by the advancements in technology used in education. All problems in the learning process are easily solved with modern media. This situation makes teachers/lecturers and learners will experience difficulties due to dependence if far from the media. On the other hand, media that can be developed from simple materials can be utilized with potential around the environment. In the learning process, learning media is one of the main supporting factors in creating a comfortable and enjoyable learning atmosphere. At present, there is no need to use modern media at high prices. It is necessary to change the perspective in learning activities. Certainly, by emphasizing sensitivity to creative things without having to spend a lot of money.

Speaking is one of the language skills mastered by learners in learning English. One of the problems faced in the learning process was the lack of students' speaking interest in English courses in the Mechanical Engineering majoring because English is not their native language, but also the lack of motivation from these students to learn English. 
Teaching and learning process is often faced with abstract material and it is far from the daily experience of students, often the material becomes difficult to be taught by the teacher/lecturers and difficult for students to understand. Visualization is one way that can be conducted to concretize something abstract. Two-dimensional images or three-dimensional models are visualizations that are often conducted in the teaching and learning process (Daryanto, 2010). Based on the explanation above, the author utilizes waste from machine spare parts as a three-dimensional form in order to facilitate the learning process, especially students' interest in English speaking. Technically, this waste from spare parts machines would be designed to be a student's creation where the basic material got from their surroundings and those waste creations were used as an alternative to enhance students' interest English speaking at the students of mechanical Engineering majoring, the State Polytechnic of Tanah Laut. It was clear that waste from spare parts machines could be a creative learning media that was useful for lecturers or students to achieve learning outcomes.

The use of learning media from waste machines has not been there before, especially related to speaking interest because previously it was only the medium of teaching instruction. Bahtiar et al (2017) stated that PUL (Pop Up Large) Media based audio with the use of waste paper is the development of visual pop up media. In this media added audio or sound features to provide a more interesting effect when presented. The effect given to this media is in accordance with the material used in this study, which is about general advice. In addition, this media also uses paper waste in several parts. This is due to the large amount of waste paper that is not used and is left in vain. That is why researchers are interested in using paper waste in making it because besides being more efficient it will have an impact on environmental cleanliness (Bahtiar et al, 2017). Learning by utilizing garbage can make students happy and enthusiastic because having an interactive experience (Astutik, 2018).

The use of plastic and paper waste into English learning media in schools can be done by a teacher to create innovative learning. Besides making learning media by using plastic and paper waste, it can also increase creativity and a sense of concern for the environment (Rusli et al, 2018).

The resources on 'Elements and Principles of Design' made lessons interactive and involving for the pupils, students and teachers which helped the pupils to create correct and interesting practical works. With the use of the resources on 'Weaving', the pupils were able to create their practical works excellently as they saw what they were supposed to do with the help of the instructional resources (Rita \& Asante, 2016).

The aims of this learning media are the student learning activities are more interesting, interactive, able to improve the quality of student learning outcomes, positive attitude's student towards learning materials and processes and increase and direct student attention so as to increase learning motivation, especially students' speaking interest. While the benefits of this learning media are reducing environmental pollution, the learning material is clearer so that it can be understood by students and also students will learn more because the media used is interesting because it's from the basic material of the waste machine which the materials are very close to their field of expertise.

\subsection{Learning Media}

Media is anything that can be used to convey messages from the sender to the recipient in order to stimulate the thoughts, feelings, concerns and interests and attention of students in such a way that the learning process occurs.

The benefits of learning media in the learning process as follows: (a) Teaching will attract more attention of students so that it can grow motivation to learn, (b) Teaching material will be more clearly meaningful so that it can be better understood by students and allow students to master better teaching objectives, (c) The teaching methods will be more varied so that students do not get bored, (d) Students do more learning activities (Sudjana \& Rifai, 2010)

Criteria for selecting learning media that needs to be understood by language users, namely: (a) Accuracy with learning objectives, (b) Support for the content of subject matter, (c) Ease of obtaining media, (d) Teacher skills in using media, (e) Available time in its use so that the media is useful for students during teaching, (f) In accordance with the level of thinking of students (Sudjana \& Rifai, 2010). 
Based on the explanation above, the media is a message conveyed from the sender, the lecturer to the recipient (the learner) so that the information conveyed can be received to gain knowledge. In learning, the media can be interpreted as the acquisition of media knowledge, skills and attitudes in the learning process, in this case the source of the message received is courses.

\subsection{Speaking skills}

In general, the teaching of speaking skills in English is more emphasized on the language system, especially the teaching of vocabulary and grammar compared to the practice of speaking (Bahrani \& Soltani, 2012). The meaning of speaking is the ability of someone to produce words that represent opinions, intentions or feelings to grow interaction with others (Haron et al, 2012). The success of foreign language learning is measured in the ability to have a conversation using the foreign language (Juhana, 2012).

Repetition (drilling) is widely used as a learning technique of speaking (Sad, 2008). This was made clear that repetition caused many students who failed to learn speaking skills or did not get the opportunity to speak which resulted in reduced learning motivation and a loss of interest in learning English (Bahrani \& Soltani, 2012).

One speaking problem faced by students occurs because they are afraid of making mistakes, accepting criticism or losing face in front of the class (Piccolo, 2010). Several psychological factors are suggested such as fear of making mistakes, embarrassment, nervousness, lack of confidence, and lack of motivation to prevent students from speaking in English in class (Juhana, 2012; Fatimah, 2019).

The findings of learning of speaking English in the classroom that the low interest of students to speak English due to lack of motivation caused by English is not their language besides that there is also no confidence to speak worried there is a fatal error. (Primary data).

From the explanation above, it can be concluded that speaking skills are very important to improve the success of learning a foreign language. However, learners are silent and do not participate in English learning process activities, they experience anxiety in practicing English speaking skills and there is no motivation to take the opportunity to communicate and improve these skills. Therefore the researcher is very confident that if there is something that does not interest the learner, it doesn't matter what the teacher teaches or the best way to teach it; In the long run, it will waste time gained just like that there must be more than one way to develop oral production smoothly, a way for students to express themselves verbally in their own words, not merely memorizing.

\subsection{Motivation}

There are three things to remember about education. The first is motivation. The second one is motivation. The third one is motivation (Former, 2009). When students feel more motivated to learn, they perform better academically, show improved classroom behavior, and gain a higher sense of self-esteem (Ferlazzo, 2015).

For the initial motivation of students, interest was a very important factor affecting their choice of university programs. Personal interest in a particular discipline or profession will be their reference for enrolment to university programs (Kember, 2016).

\subsection{Waste Machine as a Media for Learning English Speaking Skills}

The use of used goods and simple equipment as media is not new in the world of education. waste from machines' spare parts as a media for learning English speaking skills is material from unused machine waste that is reused by students to produce projects of art that will be used as a media for learning English courses, especially students' interest in English speaking. By utilizing waste machines that are goods in around them that is according to their fields Mechanical Engineering majoring which has become their science and also one of their interests in the machine. So, the interest in the project of the waste machine is able to motivate students to convey something, even some procedures for making the project because what they describe is what they produce themselves. From there the author's strategy to make the students have a desire to convey the process of making the project using English (Speaking in English) fluently. 
Raw material for learning media that was making project from waste from machines' spare parts, they were made by students. With the expectation that the next project can increase more according to students' creativity, for example; the waste of used motor shock is used as a multipurpose container such as a pencil case, flower vase, etc. From the results of the students' creativity being used as learning media, the students then explained what they had made with the basic ingredients of the machines' spare parts not far from their fields and environment. One of the following student's project is the media that can be applied to learning English, especially speaking English interest can be seen in the Figure 1:

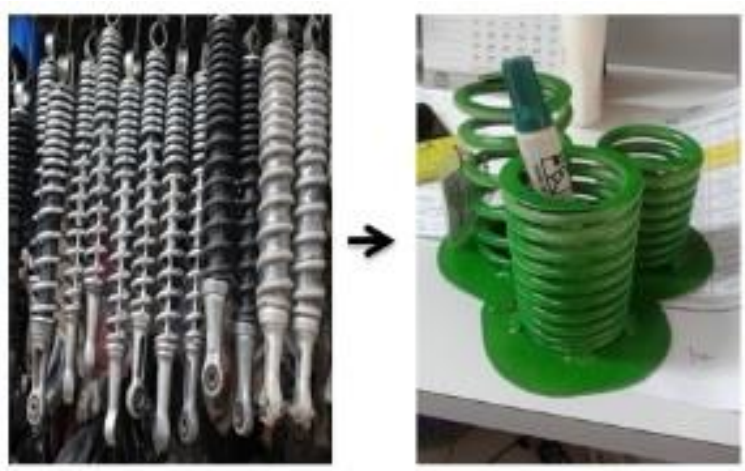

Fig. 1. One of the Students' Projects that Can Be Applied in Learning English

Based on Regulation of the Minister of Research on Technology and Higher Education Number 14 in 2015 concerning the National System of Research, article 1 paragraph (3) stated that Innovation is a research, development and / or engineering activity aimed at developing research with new values and contexts of knowledge, or new ways to apply science. and technology that is already in the product or production process. " In paragraph (4) stated that Technology is a method or method and process or product resulting from the application and utilization of various scientific disciplines that result in an increase in added value in producing products.

The implementation that will conducted in accordance with Regulation of the Minister of Research on Technology and Higher Education Number 14 in 2015 article 1 paragraph (4) is to make products of creativity and innovation by utilizing waste machines that are made into learning media for mechanical Engineering students that can be used to train students to speak English by explaining the procedure of making works of art they made themselves with the theme of the machine, which machine is their field. So, the research makes Creativity and Innovation as a trigger to develop learning media products (Regulation of the Minister of Research on Technology and Higher Education, 2015)

\section{Research Method}

This study employed a descriptive qualitative approach by conducting a case study. The participants consist of 22 students in Mechanical Engineering the State Polytechnic of Tanah Laut. They have skills from they learned before, they are also able to master English, this is reflected in the results of daily's score, especially pronunciation, reading, vocabulary and there are still obstacles to speaking for those who they do not have the desire to speak English because it is considered wrong and not their native language and they also have no initiative to speak in English. The data were collected based on the characteristic of descriptive qualitative research; they are observation, field notes, and interview. Observations were conducted to determine students' participation and responses in speaking activities. That was conducted in one semester (16 meetings). Students presented their projects to identify the development of verbal communication skills, it had observed using the checklist guidelines. After observation, discussions were conducted to confirm the findings and to receive feedback about the learning process and the speaking interest of the participants. The discussion focused on students' interest, expression skills, language communication, understanding of assigned topics, and presentation techniques. Open-ended questionnaires were intended for respondents to get their responses in the form of written data. Interviews were conducted to obtain more information about students' motivation and confidence to speak English. Questions revolve around observations and evaluations. 
The student's task is to make a project in the form of a product of student creativity from waste from spare parts of the machine, one of which is a spring simulation and there are several projects made also. Students are asked to explain what has been made and explain how to make it and the working process of the product in English.

\section{Findings and Discussion}

English for communication courses are English courses in fourth semester majoring in Mechanical Engineering. Utilization of machine waste used in the course involves activities in faceto-face learning arrangements that are routinely conducted once a week for sixteen meetings. This showed that an additional model of Waste Machine Utilization was used in the English for communication course. At each meeting the material English for communication had been arranged so that students were skilled in speaking to face the world of work. In the practice of speaking, the researcher added a learning model at each meeting, namely by utilizing machine waste as a medium to make students' speaking interest increase. All of the waste spare parts that could be utilized be processed into useful products and the results of these products are used as learning media for students in speaking English, while still seeking media according to their field created their own interest for them to speak.

During the semester, students in class were happy to attend class activities and they found teaching assignments very useful. They motivated themselves and their friend day after day. Students in the class were interested in learning English with the help of this class activity that was by utilizing waste of spare parts machine and processed into a useful product and they thought that learning English with this class activity would certainly be useful and efficient because it could increase the speaking interest of each student because it is a familiar thing for them to talk about their field, it was machine.

During the learning process, all students received very useful teaching assignments and they told that they enjoyed attending the learning process seriously and happily.

Students who know how to appreciate and implement the learning process happily and sincerely until the end of the meeting, they appreciated their own courses and this efforts in teaching English to enhance speaking interest can be said to be successful for them because they are able to attract attention and increase motivation to learn English, especially speaking.

\subsection{Enhancing Motivation}

Using the waste of spare parts of the machine intrigued the students, as soon as they had their eyes on it, it commanded complete attention. It engaged students and they enjoyed the interactive nature of the learning media. Activities could be planned or spontaneous and seemed to create heightened interest and were memorable partly because of the interactivity involved in utilization of waste of the spare part machine.

The strength of waste of the spare part machine was that the project high quality from the waste machine drew the students to enhance speaking interest. It had more immediacy than a book.

Motivation to learn seemed to come from enjoyment of learning. The terms "happy" or "enjoyment" were mentioned ten times by the participants when they talked about their learning experience. They considered learning as their "happy event."

"I have been enjoying this learning. I feel happy using this media for speaking" (RB)

\subsection{Enhancing Learning}

The utilization of the waste machine made students become more interested and became very knowledgeable about speaking from their project from waste of machine. This learning was embedded in students' experience and they developed speaking and comprehension skills. Possibly, the most marvelous utilize of the waste machine was in speaking sessions, part of our oral language and skill-building program as inquirers.

"This is interesting, it can make me speak fluently...." (EBS) 


\subsection{Students Activities}

There are several activities as addition to the learning model identified in the English for communication course, they are:

\section{1) Design Project}

Waste of the spare part machine could be obtained from workshop Mechanical engineering or other workshops that which unused. Spare parts are chosen according to the needs of the project to be made. Before that students designed projects that will be created with unique with a unique name from the project.

\section{2) Making project}

The project was made in the workshop of the State Polytechnic of Tanah Laut by taking into account the preparation of tools and materials for making the project. The project was made directly by students in accordance with the designs that have been made before so that students are able to explain it themselves later because the project is related.

This machine waste processing project was made according to the design of students who have high value and only need materials from the waste of the machine while the tools can use welding machines in the workshop of Mechanical Engineering. This innovation is expected to be able to support the government's efforts to deal with waste, especially waste of spare part, and it will also encourage the management of the waste machine in the future.

\section{3) Present Project}

After the results of the project were completed, then students presented the results of the project by conveying some of the tools and materials used in making the project. In addition, the project was also delivered with the procedures to make it and how to work the project. It was the final step for students doing the English speaking. Presentation assignment was conducted outside classroom hours to give students plenty of time to implement the steps in the presentation process, one of which was to explain the steps of making projects to produce speaking well and have an interest in speaking. From interviews, students admitted that this activity helped them a lot in increasing their interest in speaking and also their speaking skills.

\section{4) Feedback}

The other students gave corrective feedback from the presenter. Although the lecturer already asked students to pass their comments on their friends' presentation, only a few students give comments to their friends' work since it was not compulsory. Therefore, if it is considered necessary to have feedback, such as for peer-review activity or for increasing student-to-student interaction, the activity should be made compulsory

\section{Conclusion}

Speaking is the most challenging skill in language learning. However, the choice of various techniques and activities can make it easier for students to learn. One technique that can support language learning, especially speaking, is the use of a waste machine. For technically, students utilize waste from machines' spare parts, talk and explain the products they have made according to the work processes that have been conducted. These activities were found encouraging when wrapped in interesting activities and based on teacher specialization. Students demonstrate their enthusiasm and commitment in using this exercise. Therefore, they find this approach interesting and it is therefore suggested that this technique can be one of the techniques to consider when teaching speaking in improving students' speaking skills.

\section{Acknowledgment}

This research was supported by Directorate of Research and Community Service Directorate General of Strengthening Research and Development Ministry of Research, Technology and Higher Education In accordance with the Research Contract Fiscal Year 2019. 


\section{References}

Astutik, P.P. (2018). Pembelajaran dengan memanfaatkan media sampah untuk meningkatkan kemampuan literasi dan keterampilan berpikir kreatif siswa sekolah dasar. Jurnal Dikdaktika Pendidikan Dasar, 2(2), 159.

Bahrani, T., \& Soltani, R. How to teach speaking skill. (2012). Journal of Education and Practice, 3(2), 2529.

Bahtiar, R.S. (2017). Media PUL (Pop Up Large) berbasis audio dengan pemanfaatan limbah kertas sebagai optimalisasi pendidikan beretika pada siswa Sekolah Dasar. AUTENTIK, I(2), 65-66. ISSN 2548-9119

Daryanto. (2010). Media pembelajaran. Yogyakarta: Gava Media.

Fatimah, S. (2019). Collaborative learning activities through MoE in engaging EFL learners and diminishing their foreign language anxiety. English Language Teaching Educational Journal, 2(1),39-49, https://doi.org/10.12928/eltej.v2i1.925

Ferlazzo, L. (2015). Self-motivated learners: Strategies to help students thrive in school and beyond. Philadelphia: Routledge.

Former, U.S. (2015). Secretary of education Terrel Bell; in Hacker, Dunlosky, \& Graesser, 2009 in Ferlazzo, self-motivated learners: Strategies to help students thrive in school and beyond. Routledge.

Haron, S.C., Ahmad, I.S., Mamat, A., \& Ahmed, I.H. (2012). Using media to enhance Arabic speaking skills among Malay learners. Journal of Education and Practice, 3(9), 82-87.

Juhana. (2012). Psychological factors that hinder students from speaking in English class (A case study in a senior high school in South Tangerang, Banten, Indonesia). Journal of Education and Practice, 3(12), 100-110.

Kember, D. (2016). Understanding the nature of motivation and motivating students through teaching \& learning in higher education. New York: Springer.

Piccolo. (2010). Tips for successful speaking activities in the ESL Class. Retrieved from Suite101: https://suite101.com/a/tips-for-successful-speaking-activities-in-the-esl-class-a262535

Rusli, T.I., Ndibale, W., \& Atika. (2018). Lipstik (limbah plastik dan kertas) sebagai media pengajaran bahasa Inggris di sekolah dasar negeri. JURNAL JPSD, 5(1), 32-38.

Sad, S.N. (2008). Using mobile phone technology in EFL classes. English Teaching Forum. 4, 34-40.

Sudjana, N., \& Rivai, A. (2010). Media pengajaran. Bandung: Sinar Baru Algensindo.

Yeboah, R., \& Asante, E.A. (2016). Teaching interactive art lessons with recycled waste materials as instructional resources. Journal of Education and Practice, 7(14), 57. www.iiste.org ISSN 2222-1735 (Paper). ISSN 2222-288X (Online). 